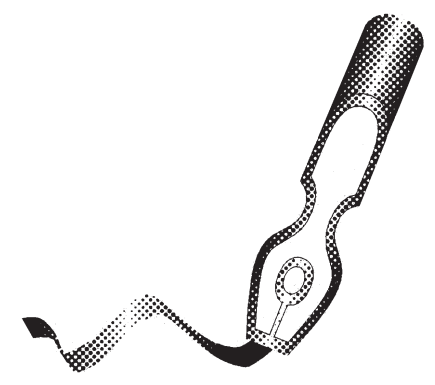

\title{
Revista de Otorrinolaringología
}

Es una revista "Open Access", sin costos de publicación para los autores. Figuras y tablas se publican en blanco y negro. Las figuras que necesiten ser a color pueden ser de costo del autor y debe ser solicitado.

Los trabajos enviados a "Revista de Otorrinolaringología y Cirugía de Cabeza y Cuello" deben ajustarse a las siguientes instrucciones preparadas y al "ICMJE Recommendations" establecidas por el International Committee of Medical Journal Editors y disponibles en www.icmje.org.

Los trabajos deben incluirse en la plataforma electrónica en sección nuevo. Para acceder a la plataforma puede ingresar a www.sochiorl y en ella a publicación de trabajos on line. Otra forma de ingreso es www.itsolutionconsultores.com/orl/login. php?= . Los trabajos de investigación debe incluir todos los ítemes solicitados (tipo de artículo, títulos, autores, resumen, etc.) tal como será publicado, en un archivo Word con formato carta, letra Times New Roman o Arial tamaño 12, interlineado a 1,5 líneas y justificado a la izquierda dejando un margen de $3 \mathrm{~cm}$ en los bordes. La revista recibe trabajos a publicar en algunas de las siguientes secciones, artículos de investigación (máximo 4.000 palabras), casos clínicos (máximo 3.000 palabras), artículos de revisión (máximo 5.000 palabras), artículos de ética (máximo 1.500 palabras) y cartas al editor (máximo 1.500 palabras).

En cualquiera de sus secciones la página del título y la primera hoja debe incluir el título del trabajo, nombre de pila, el apellido paterno y la inicial del materno de cada autor. Al término en superíndice, indicar un número de identificación. Su calidad profesional y su identificación de trabajo debe ir a pie de página. En esa zona sólo debe tener identificación del lugar en donde el trabajo fue realizado. La Identificación del contacto debe tener nombre, dirección y email del autor correspondiente. Las jerarquías académicas de posgrado de cada integrante no deben ser incluidos. En la sección pertinente de la plataforma es exigencia indicar si la publicación cuenta con la autorización de Comité de Ética de la institución y colocar allí el $\mathrm{n}^{0}$ del protocolo de bioética aprobado y si ella es concordante con la Declaración de Helsinki de la AMM (2013) y con la Ley 20.120 y 20.584 de la República de Chile. También es exigencia indicar si existe autorización o consentimiento para 
publicar datos, fotos 0 imágenes. En el caso de 60 más autores se debe explicar cuál fue la contribución de cada coautor. Los autores deben declarar si tienen conflictos de interés con alguna institución privada que se relacione al estudio. El resumen debe ser en español y el abstract en inglés, de no más de 250 palabras cada uno.

En los casos clínicos y los artículos de ética y de revisión, el resumen será global. En el caso de los artículos de investigación el resumen será estructurado en el siguiente esquema: Introducción, Objetivo, Material y método, Resultados, Discusión, Conclusiones y palabras clave. En estas últimas se recomienda elegir de la lista " MeSHHeadings del Index Medicus accesible en www.nim.nih.gov/mesh o en Google MeSH Browser. Se recomiendan al menos 4 palabras clave.

Los contenidos de las páginas del texto en trabajos de investigación se detallan latamente en la página de la Sociedad en donde además se declara la concordancia con la declaración de Helsinski de la AMM (2013) y las leyes vigentes en Chile. Se recomienda mencionar el método estadístico empleado, así como su nivel de significación. En trabajos de estudios observacionales recomendamos seguir directrices Strobe en www.strobestatement.org/.

Los autores son responsables de la exactitud de sus referencias bibliográficas, numerando las referencias consecutivamente en forma de superíndice, de acuerdo al orden en que se mencionan en el texto. La forma de citar la bibliografía está basada en el formato que la Biblioteca Nacional de Medicina de los Estados Unidos y que es usada en el Index Medicus. Ejemplos de como realizarla las citas bibliográficas deben buscarse en www.sochiorl.cl.

Para las referencias electrónicas, deben citarse primero los autores, el título del artículo, la revista de origen en caso que el trabajo estuviese publicado en ellas indicando disponible en: y al finalizar la cita electrónica las palabras: Consultado el: (fecha).

Para los casos clínicos y trabajos de revisión se recomienda tener un texto con un resumen en español y en inglés de no más de 250 palabras cada uno. El texto debe tener 3.000 palabras como máximo en los casos clínicos y no más de 5.000 palabras en los artículos de revisión. Ambos tipos de trabajos deberán estar basados en las recomendaciones señaladas con sugerencias de lectura www.scielo.cl/revistas/rcp/einstruc.htm http://www. scielo.cl/revistas/rmc/einstruc.htm

La revista Otorrinolaringología y Cirugía de Cabeza y Cuello aconseja revisar la página www.espanol.equator-network.org/home la cual es una ayuda a autores tendientes a una mejor presentación. Recomendamos revisar en detalle esa página.

También recomendamos las instrucciones a los autores de revista Médica de Chile y la de la Revista de Pediatría: http://www.scielo.cl/revistas/rmc/einstruc.htm. y www.scielo.cl/ revistas/rcp/einstruc.htm respectivamente. 